\title{
CONTRIBUTIONS FROM THE ROCKY MOUNTAIN HERBARIUM. III.
}

AvEN NELSON.

\section{STUDIES IN ERIOGONUM.}

THis genus is remarkably well represented in Wyoming. Since most of the species in it are peculiar to arid America, any of the states with desert areas may be expected to represent a considerable number of the increasingly long list of species. A line drawn from central Wyoming to western Arizona will divide into somewhat equal parts the Eriogonum belt.

No recent revision of the genus has been published, but a considerable number of new species have appeared. When one considers how extensively collections have been made in the arid west indicated above, it seems rather remarkable that Dr. Watson's revision of twenty-five years ago (Proc. Am. Acad. r2:254) should so nearly represent our knowledge of these plants as it does. That a revision is now needed I think all will admit, but until some one finds time and occasion to do so, notes upon and additions to the species may not be out of place.

Eriogonum orendense, n. sp.-Caudex woody, almost wholly subterranean, its numerous branches densely tufted: tomentum rather dense, uniform throughout the plant, giving it a greenishwhite hue: stems numerous, crowded, very short, exclusive of the woody persistent base not to exceed $5^{\mathrm{cm}}$ : leaves numerous, crowded, narrowly oblong or oblanceolate, subacute, $\mathrm{I}-3^{\mathrm{cm}}$ long, tapering into a slender petiole which usually exceeds the blade: scapes erect, $7-\mathrm{I} 5^{\mathrm{cm}}$ long, surpassing the leaves: inflorescence umbellate, with short subulate bracts; the rays unequal, $\mathrm{I}-2^{\mathrm{cm}}$ long, terminating in a few-flowered cyme (3-7), with very short connate bractlets: involucres short-peduncled $(\mathrm{I}-3)^{\mathrm{mm}}$, turbinate, merely toothed around the summit, about $3^{\mathrm{mm}}$ long, many-flowered (8-12): calyx bright yellow; the segments 1902] 
similar, scarcely $2^{\mathrm{mm}}$ long, oblong, obtuse, the slender pedicels intermingled with setae bearing stipitate glands and a few fine slender hairs: filaments linear, sparsely pubescent to above the middle: styles slender, long exserted : ovary glabrous; mature akene not seen.

Probably most nearly allied to E. campanulatum Nutt., though very different from that and blossoming much earlier in the season. The proposed species was found in full bloom June I I, I 900, on the stony slopes of Orendo butte, in the Red desert. This is very early in the growing season in this range. E. campanulatum, in this same range, blossoms late in the season, and is a much larger plant, with a compound inflorescence as well as a number of minor floral differences. The type no. is 7143, collected as above.

Eriogonum ovalifolium Nutt.- There is perhaps no species in the genus more variable as to color of flowers than this, if the specimens as named in the herbaria are to be considered the only evidence. Nuttall originally distinguished two species in the present aggregate and consistently maintained them both. E. ovalifolium was applied to the form with "bright sulphuryellow" perianth, which occurs in greater or less abundance on the arid table-lands about the "sources of the Missouri." Of the allied forms, however, this was the less abundant, so that by this time the mention of E. ovalifolium suggests not the original, but the E. purpureum of Nuttall. That this is the case is easily verified by referring to Jour. Acad. Philad. 7:50, and to Jour. Acad. Philad. new ser. $1: 166$, in the latter of which these two species appear under the there proposed genus Encycla.

Whether the two can be maintained as distinct species may well be questioned, but there are the best of reasons for retaining the later one as a variety. Not the color of the perianth alone, though in regions in which both grow I have seen nothing to indicate that they intergrade, but the differences (though slight) as given in the publications cited indicate at least varietal rank, as suggested in DC. Prod. 14: 10. Accordingly the white-flowered form, which almost constantly shows traces of purple or may even become of a deep purple hue (never yellowish ?), may be designated 
Eriogonum ovalifolium purpureum, n. comb.-Encycla purpurea Nutt. Jour. Acad. Philad. new ser. I : I66; DC. Prod. l. c.

Eriogonum crassifolium Benth. Trans. Soc. Linn. Lond. I7 : 408; Hook. Fl. Bor.-Am. pl. I76. E. aureum Nutt. in. DC. Prod. r4:8.- This excellent species has for a long time been wholly in eclipse, or at most has been accorded only varietal rank. It is most abundant in the type locality, "Scopulosis ad regionem super. fl. Platte." It has several times been collected by the writer and distributed as a variety of E. flavum Nutt. Again collected in I9OO as no. 7285 in quantity, and will be distributed as a species, which it properly is.

ERIOGONUM CRASSIFOLIUM tectum, n. var.-Densely tufted with deep set woody roots, the crowns of the branched caudex inordinately enlarged by the thick, closely sheathing, very woolly leaf bases: leaves all crowded on the short crown, firm and thick, densely tomentose, ovate to oval or more rarely oblong, $2-3^{\mathrm{cm}}$ long, on very short petioles ( $1 / 4$ to $1 / 2$ as long): scapes stout, about $I^{\mathrm{dm}}$ long: flower yellow, but the yellow obscured by the long, dense, tomentose pubescence of the involucres and calyx-segments: inflorescence subcapitate, the rays mostly shorter than the foliar bracts.

The variety may readily be known by the remarkable protection against desiccation and cold that is afforded the crowns of the caudex, and the whole plant for that matter, by the dense tomentum. That is a character of the species, but in a small degree when compared with the variety. The shorter petioles and rays and the thick, leathery leaves further distinguish it. The species comes into blossom in June, while the variety in the same range not till August. Only one no. of the variety is at hand, 204I, Sand creek, Albany co., Aug. 8, I896, on dry, sandy, eroded banks.

Eriogonum fruticosum, n. n.-E. aureum Jones, Contrib. to W. Bot. 7: 7 I8; not E. aureum Nutt. DC. Prod. 14:8.

ERIOGONUM FRUTICOSUM ambiguum, n. comb.-E. aureum ambiguum Jones, Contrib. to W. Bot. $7: 7$ I9.

ERIOGONUM FRUTICOSUM glutinosum, n. comb.-E. aureum glutinosum Jones, Contrib. to W. Bot. 7 : 7 I9.

Eriogonum laxifolium.-E. Kingii laxifolium T. \& G. Proc. Am Acad. 8: I65 ; E. chrysocephalum Gray, Proc. Am. Acad. I I : IO I 
Malvastrum dissectum, n. comb. - Sida dissecta Nutt., Torr. \& Gray, Fl. I:235; not Malvastrum coccineum Gray, Pl. Fendl. 24; Gray, Pl. Wright. I : I7; nor $M$. dissectum Cockerell, Bull. Torr. Bot. Club 27:87.- Perennial: many-stemmed from a multicipital caudex, $2^{\text {dm }}$ high or less, densely cinerously stellate-pubescent, the stems whitened with the closely appressed hairs, the calyx obscurely glandular beneath the pubescence: leaves small, $\mathrm{I}-3^{\mathrm{cm}}$ broad, pedately $3-5$-parted, the divisions incisely lobed, the lobes narrowly oblong to linear: racemes several-flowered, pedicels $2-5^{\mathrm{mm}}$ long; flowers scarlet: the petals obovate, nearly truncate and merely emarginate; the stigmas capitellate.

That Nuttall was justified in separating this from $M$. coccineum seems perfectly evident to any one who has seen both species in their native habitat. It is at once distinguished from $M$. coccineum (Nutt.) Gray by its cinereous white aspect, by its smaller and more narrowly lobed leaves, and narrower petals. There can be no question which species Nuttall meant to designate Sida dissecta, when one reads the notes and descriptions relating to these two species in Fl. N. Am. The Cristaria coccinea Pursh, Fl. 2:453, Malva coccinea Nutt. Gen. 2:8I, and Sida coccinea T. \& G. Fl. 235, undoubtedly refer to the same plant, viz., the broad-leaved form so common on the great plains between the Rocky mountains and the Missouri river. Sida dissecta of the T. \& G. Flora is clearly the plant still found on the high saline desert table-lands, "sources of the Platte near the Rocky mountains." Were more evidence needed to show that $S$. dissecta designates the more western plant, it is found in the fact that the Sida dissecta Hook, and Arn. Bot. Beechy, Suppl. 326 , is considered by Torrey and Gray (F1. N. A. 682) as identical with the Nuttallian plant.

On the other hand, Dr. Gray did not consider the plants of Pl. Fendl. and Pl. Wright. as identical. In the former he uses this expression " * * a few specimens of the var. dissecta, or of forms that evidently connect the Sida dissecta of Nuttall with $S$. coccinea." In the latter, the language is " * * a more canescent variety, * * approaching the var. dissectum."

These southern narrow-leaved forms, nicely distinguished from Malvastrum coccineum by Professor Cockerell, are far enough from the Nuttallian dissectum. They may therefore be designated -

Malvastrum Cockerelli, n. n.- $M$. dissectum (Nutt.) Cocker- 
ell, Bull. Torr. Bot. Club 27:87. M. coccineum dissectum Gray, Pl. Fendl. 24 ; and Pl. Wright. I : I 7 .

Malvastrum elatum. - M. coccineum elatum E. G. Baker, Jour. Bot. 29: I 7I. - This plant, originally published as a variety, is so different from the true $M$. coccineum that it is less confusing to consider it a species. It is not only much larger, with broader leaf-segments, but its more erect habit and tendency to paniculate branching give it the aspect of a Sphaeralcea. Its pubescence is less conspicuous, and the carpels not so evidently reticulate-veined, and the sepals shorter and more abruptly acute. It occurs very sparingly. I have twice collected it, both times at Evanston, Wyoming.

Cerasus demissa melanocarpa, n. var. - Varying from a small shrub to a tree-like one, $4-5^{\mathrm{m}}$ high: leaves smooth or nearly so on both sides, the teeth of the fine serration incurved or appressed; petioles not glandular: raceme of white flowers compact, erect or ascending: fruit when fully mature black.

The Rocky mountain form of Cerasus demissa is clearly, at least varietally, distinct from the original Nuttallian specimens. Nuttall's specimens from "The plains of the Oregon towards the sea, and at the mouth of the Wahlamet," differ from the more eastern form in the pubescent leaves which are serrate with straight teeth and with glandular petioles; more evidently yet in the red fruits which are sweeter and less astringent than the black ones.

The variety proposed is in many respects intermediate between typical Cerasus virginiana of the eastern states and typical $C$. demissa of the far west. All the Rocky mountain specimens seen by me are of this variety.

Gentiana Bracteosa Greene. - In publishing this species (Pitt. 4:180) Professor Greene lays stress upon the narrowness of the leaves, but I am satisfied that this character will not distinguish it from G. Parryi. Some fine specimens collected by Mr. H. N. Wheeler, Camp Albion, Colorado, Aug. 30, I90 I, have the floral characters of $G$. bracteosa, but typical leaves of G. Parryi. Furthermore, in some specimens of G. Parryi the stems in the same clump vary as to the leaves from narrowly oblong to broadly ovate. The species I think will stand, however, on the bract characters, and a peculiarity of the spathaceous cleft calyx not pointed out by Dr. Greene. The calyx-tube 
is membranous at summit, and its oblong or elliptic short green teeth are seemingly not a continuation of the tube, but are inserted below the margin, on the outside, and often scarcely exceeding its membranous rim. Unless these characters are distinguishing, it will have to take varietal rank.

Gentiana strictiflora (Rydb.).-G. acuta strictiflora Rydb. Mem. N. Y. Bot. Gard. I : 309. I900; full citation given in the same place. - This well deserves specific rank. It has quite as good characters as the allied species G. acuta, G. tenella, and $G$. heterosepala. Its large size, strict habit, numerous flowers, and the distinctly ochroleucous corollas are wholly characteristic. Common in moist swales on bottom lands.

Gentiana calycosa xantha, n. var. - Habit of the species, smaller, $I^{\mathrm{dm}}$ or less high: leaves about five pairs, longer than the internodes; the single flower smaller, yellow or yellowishwhite with numerous green dots.

At first sight theseplants strike one as a decided novelty, but closer examination reveals no decisive character except the color. Even the conspicuous green dots in the corolla are not wanting in the species itself, though much obscured by the deep blue of that.

Collected by Elmer D. Merrill and E. N. Wilcox, on the Tetons, above Leigh's lake, Wyoming, July 26, I 9or ; no. i I08.

Phacelia corrugata, n. sp.- Biennial or more enduring, $3-5^{\mathrm{dm}}$ high, slightly glutinous and more glandular-pubescent: stem either branched or simple at base, the branches also sparingly branched, moderately leafy, terminating in elongated naked peduncles: leaves narrowly oblong in outline, somewhat alternately I I-I 5-lobed, the broad sinuses extending about half way to the midrib, each lobe with two to four rounded unequal lobules; petioles short or wanting: spikes very dense even in fruit, rather tardily open; pedicels very short $\left(\mathrm{I}^{\mathrm{mm}}\right)$ : sepals linear-oblanceolate, sparsely hirsute, nearly as long as the corolla : corolla blue, campanulate-funnelform, $\mathrm{I}^{\mathrm{cm}}$ or more long, as much in diameter over the limb, lobes suborbicular, internal folds short and united around the base of the filament: stamens and styles nearly twice the length of the corolla ; the undivided base of the style pubescent: capsule elliptical, about $5^{\mathrm{mm}}$ long: the seed oblong, 
obtuse at both ends, deeply excavated on the ventral side, the inner side of the lateral angles and one side of the salient central ridge strikingly corrugated by rounded, pitted papillae, minutely ridged-papillate on the base.

This has passed for a form of $P$. crenulata Torr., a plant which $I$ think is found only much farther west. That differs from the plant here described in the smaller size, more deeply lobed leaves, more open spikes, rotate-campanulate, violet corolla, with broad internal folds; the short, linear calyx-lobes; the globular capsule and reticulated, much smaller seeds.

I base the species on specimens from Colorado as follows: no. 2129 (type), G. E. Osterhout, Rifle, Garfield co., June 23, I9oo, in mature fruit ; (co-type) C. S. Crandall, Palisades, Mesa co., May I4, I898, in full bloom.

Gilia Merrillii, n. sp.- Perennial, from a short woody caudex and tap root: stems few to many from the crown, erect or spreading, sparsely woolly-pubescent, IO-I $5{ }^{\mathrm{cm}}$ long, very leafy towards the base: leaves all simple, crowded, glabrous or nearly so, linear-subulate, cuspidate, either appressed or spreading: flowers white, closely capitate, the heads large (10-20 mm in diameter): calyx lobes subulate, with a green midrib, a little shorter than the scarious tube : corolla tube $4-6^{\mathrm{mm}}$ long, exceeding the calyx lobes, its oval lobes noticeably shorter than the tube: stamens exserted, the filaments a little shorter than the corolla lobes: capsule broadly oval, longer than the calyx tube, its cells I-seeded.

In habit this species suggests $G$. congesta or $G$. iberidifolia, but the numerous short, simple leaves are wholly distinguishing even without the other characters. I name it for Mr. Elmer D. Merrill, who, in company with Mr. E. N. Wilcox, made an extensive and valuable collection in western Wyoming and eastern Idaho, in the summer of Igor. It was secured on dry soil, fifteen miles south of Leckie, Wyoming, June I5; no. 746.

Gilia Wilcoxii, n. sp.-Annual, I-3 dm high, generally branched from the base; the branches in turn sparsely branched, erect or (if several) decumbent at base, somewhat floccose woolly, tardily glabrate: leaves less woolly than the stems, alternate, $2-5^{\mathrm{cm}}$ long, pinnate; the segments narrowly linear, mucronate, the lateral ones widely divaricate, short (mostly less than $\left.\mathrm{I}^{\mathrm{cm}}\right)$, usually two pairs: flowers in small bracteate clusters 
terminating the branchlets, involved in wool especially the base of the calyx and the subtending green foliar bracts; bracts pinnately 3 -cleft, the terminal lobe surpassing the calyx: sepals 5, green, equal or nearly so, pungently mucronate, hardly united except by the enveloping wool, about $7^{\mathrm{mm}}$ long: corolla light blue, tubular, dilating into a broader throat, tube surpassing the calyx, lobes oblong, obtuse, about half as long as the tube: stamens scarcely exserted (the anthers only in the sinuses of the corolla lobes): ovules about four to each cell, not all maturing: seeds small, rhombic in outline, obscurely scarious on the angles and the tips, apparently not developing mucilage when wetted.

This is a close ally of $G$. floccosa Gray, which is a plant of Oregon, extending southwest into California. In this species it may be noted that the leaves are usually simple, the calyx of four unequal lobes, the corolla tube yellow, the anthers exserted, the seeds fewer, larger, not angled, developing copious mucilage.

Following Bentham, Mr. Howell in his Fl. N.W. Am. restores to generic rank the section Hugelia and places in it $G$. floccosa. If that genus is to stand, the species now proposed must find its way into it, but I am unable to see any valid generic characters.

Named for Mr. Wilcox, mentioned above, who with Mr. Merrill secured three collections of it, all near St. Anthony, Idaho, in July I gor ; nos. 822, 862, and 952 .

Lappula columbiana, n. sp.-Annual, $3-5^{\mathrm{dm}}$ high, hirsute with soft white hairs, those on the leaves with pustulate base: stem simple below, upward freely and divaricately branched; the branches tapering, long and slender, sparsely fruited : leaves from linear-spatulate (below) to linear, passing into the bracts which exceed the short pedicels: sepals nearly linear, $5^{-6^{\mathrm{mm}}}$ long, surpassing the fruit: corolla small, mostly light blue: nutlets similar, prickles few (7-9), united below into a shallow, involute-margined cup, finely and closely muricate ventrally, the murications on the dorsal face (disk) in about three rows, those of the middle row largest.

This is the L. texana of the Flora of the Palouse Region by Piper and Beattie; Fl. N.W. Am. Howell in part at least; not L. texana (Scheele) Britt. The latter is indeed Texan and not well known. Neither may it be considered L. cupulata (Gray) Rydb. (See Bull. Torr. Bot. Club 28:3I). Now 
that the old and troublesome aggregate has been broken up, there is no way left except to constitute this a species. Its range seems to be in the region of the tributaries of the Columbia. Three collections are represented before me: no. I703, C. V. Piper, Alamota, Wash.; A. A. \& E. Gertrude Heller, Nez Perces co., Idaho; L. F. Henderson, Lewiston, Idaho.

Lappula cucullata, n. sp. - Sparingly cinereous-pubescent throughout: tap-root slender : several to many-stemmed from the crown, the stems simple or sparingly branched, only $\mathrm{I}-2 \mathrm{dm}$ high: leaves numerous, small, narrowly oblong, $\mathrm{I}-3^{\mathrm{cm}}$ long, passing into the small foliar bracts: nutlets similar, and all deeply cupulate or hooded, the border of the hood thin and strongly involute, the rounded margin bearing a few short glochidiate prickles, the tip of the nutlet with nearly an equal number of slender prickles not involved in the border of the hood (these characters not fully developed till maturity); the body of the nutlet with a dorsal slightly muriculate ridge, ventrally orbicular with an abrupt acumination, strongly keeled, the sides closely muriculate.

This has possibly its nearest ally in L. heterosperma Greene, but is somewhat differently branched, is less cinereous, and has the nutlets all alike.

The type number is 7250 , Fort Steele, Carbon co., Wyo. Dry, sandy slopes.

LAPPUla heterosperma homosperma, n. var. - Larger than the species, paniculately branched from the base upward: nutlets all similar and with the characters of the cupulate ones of the species.

Specimens of the variety by Mr. G. E. Osterhout, New Windsor, Colo., June 23, I899.

Cryptanthe depressa, n. sp.- A small depressed annual, freely and divaricately branched, $3-6^{\mathrm{cm}}$ high and more widely spreading, the dense pubescence soft-hispid, white with a slight fulvousness in the inflorescence: leaves small, linear, IO-I $5^{\mathrm{mm}}$ long: flowers minute: sepals linear, shorter than the corolla: corolla $2^{\mathrm{mm}}$ long, its lobes less than half the length of the slender tube: anthers below the middle of the tube: nutlets ovate, acute, smooth, the linear scar nearly closed and forked at the base, more than $\mathrm{I}^{\mathrm{mm}}$ long. 
It has the aspect of some of the species of the deserts of the southwestern United States, but I am unable to find a close ally.

Collected by Messrs. E. D. Merrill and E. N. Wilcox, dry soil, seven miles west of St. Anthony, Idaho, July 8, I89I ; no. 873.

Cryptanthe Howellii, n. n.- C. multicaulis Howell, F1. N. W. Am. 487; not C. multicaulis Aven Nelson, Bot. Gaz. 30: 194.This species may appropriately be named for its discoverer and describer, the indefatigable student of our northwestern plants, Mr. Thomas Howell.

Oreocarya cana, n. sp.-The multicipital caudex tufted, its branches clothed at their summits with the densely pubescent leaf bases: stems single from the crowns, I-2 dm high, simple, softly and closely pubescent: leaves silvery white with a short, close, soft pubescence; the numerous crown leaves linearoblanceolate, $3-7^{\mathrm{cm}}$ long, scarcely petioled; stem leaves shorter, sessile above: inflorescence a short dense thyrsoid spike, its pubescence moderately dense and slightly fulvous (scarcely hispid): sepals linear, 5- $7^{\mathrm{mm}}$ long: corolla white, its tube as long as the calyx : nutlets narrowly ovate, angled at the sides, densely muriculate on the back and sides, ridged on the back by a double row of minute tubercles, scar open lanceolate, about $3^{\mathrm{mm}}$ long, rarely all maturing.

This plant was first collected in 1894 , and now again from near the same locality in excellent flower and fruit. In habit it is intermediate between $O$. suffruticosa Greene and O. caespitosa Aven Nelson, but perhaps more nearly allied to the latter, from which it is at once separated by its silvery white foliage, its larger size, and muricate nutlets. No. 8309, collected on gravelly, open hilltops, Fort Laramie, Wyoming, is the type.

Mimulus membranaceus, n. sp.-A weak diffusely spreading annual, nearly glabrous throughout, but slightly clammy in the fresh state: stems slender, nearly prostrate, geniculate at the nodes, from a few centimeters to $\mathrm{I}$ or $2^{\mathrm{dm}}$ long: leaves very thin, elliptic to broadly ovate, entire or crenate-dentate, on pedicels about equaling the blade: flowers in the axils, on filiform pedicels which are several times longer than the calyx: calyx tubular, obscurely glandular-pubescent, $2-3^{\mathrm{mm}}$ long, the teeth small, much elongated, somewhat inflated and distinctly angled 
in fruit: corolla yellow, very moderately bilabiate, nearly tubular, $5-8^{\mathrm{mm}}$ long: capsule not stipitate, elliptic, obtuse, nearly equaling the slender style which barely protrudes from the mature calyx: seeds nearly oval, very small.

This is the counterpart in this range of $M$. alsinoides Benth. of the Washington-Oregon flora. From that species $M$. membranaceus differs principally in the enlarged and angled calyx, the scarcely bilabiate corolla (without the purple spot on the lip), and in the obtuse capsule and orbicular seeds.

Of the three collections of this all were secured in the Medicine bow mountains, always growing more or less in the shade of wet rock ledges and cliffs; nos. I5I5 (I895); I683 (I895), type; and 7729 (I900).

Mimulus Lewisin tetonensis, n. var.-Smaller than the species in every way, more granular-glandular: calyx lobes shorter, narrowly linear-acuminate: corolla shorter, white or tinged with yellow.

Collected by Elmer D. Merrill and E. N. Wilcox in the Tetons, Wyoming, at I I,000 ft., near Lee's lake, July 26, I90 i ; no. I072.

Pentstemon comarrhenus Gray - I wish to call attention to the distinctness of P. comarrhemus Gray (Proc. Am. Acad. r2:8I) and $P$. strictus Benth. (DC. Prod. ro:324). P. strictus in Gray Syn. Fl. 2: 262 seems to include both, though probably referring mainly to the plant of Utah and western Colorado. P. strictus was founded upon immature specimens collected by Fremont on the Platte river in Wyoming, where it is abundant, though apparently not again collected until within the last few years, hence the confusion. Good specimens of the two species when compared leave no doubt as to the validity of both. Typical specimens of $P$. strictus are my nos. I 472, I 579, 3079, and others from Wyoming and adjacent Colorado. Of the other species Mr. M. E. Jones's no. 5484, Castle gate, Utah, seems to me to be typical. Mr. Baker's no. 604, Piedra, Colo., will also probably go here.

Pentstemon xylus, ${ }^{x}$ n. n.-P. caespitosus suffruticosus Gray, Syn.

${ }^{x}$ This description and the notes upon it were written before I discovered Dr. Rydberg's Penistemon suffrutescens, Bull. Torr. Bot. Club 28:503. From the very limited notes there given I judge that he and I are considering totally different plants. As I feel quite certain that I have the true P. caespitosus suffruticosus Gray, I still present this description. If I be right, Dr. Rydberg's $P$. suffrutescens is practically a nomen nudum until he presents a description of it. 
Fl. 10: 270 ; not $P$. suffruticosus Dougl., Benth. in DC. 10:330.Caudex woody, its branches prostrate spreading: the annual herbaceous stems slender, erect, not crowded, sparsely leafy, finely puberulent, $\mathrm{I}-2^{\mathrm{dm}}$ high : leaves linear-oblanceolate to spatulate, acute or obtuse at apex, tapering very gradually to the slender base, $\mathrm{I}-2^{\mathrm{cm}}$ long, shorter than the internodes, nearly or quite glabrous : inflorescence open; the short peduncles at right angles to the stem, with about three short-pediceled, nearly erect flowers: sepals nearly linear, sparsely glandular-pubescent, about $4^{\mathrm{mm}}$ long: corolla moderately ventricose, with sub-equal lipś, obscurely and sparsely glandular pubescent, a few long hairs in the throat: the sterile filament moderately bearded to its base.

The specimens before me were collected by Mr. H. N. Wheeler at Sapinero, Colo., 1898 , no. 446 , and in my judgment are referable to $P$. caespitosus suffruticosus Gray. As suggested by Dr. Gray, this seems to be a distinct species, though clearly related to $P$. caespitosus.

Pentstemon Owenii, n. sp.-Perennial from a much branched, cespitose, woody caudex, $\mathrm{I}-2^{\mathrm{dm}}$ high : stems numerous, erect from a more or less decumbent base, rather slender, glabrous, or with an obscure puberulence, most of them tinged with purple, some of them deeply so: leaves glabrous, numerous on the crowns of the caudex (many of the branches of the caudex terminating in short, slender, sterile, leafy shoots), narrowly elliptic (some of the earlier ones from obovate to spatulate), mostly acute at apex, $2-4^{\mathrm{cm}}$ long, tapering cuneately at base into a petiole which is usually much shorter than the blade (rarely nearly equaling it); the stem-leaves several, the lower much like those of the crowns, becoming narrower and lanceolate upward, passing into the bracts of the inflorescence: thyrsus crowded, from capituliform to short spicate and somewhat interrupted-verticillate, minutely glandular-pubescent especially on calyx and pedicels: sepals lanceolate, one-third as long as the corolla, the broadish base scarious margined, the green central portion continued into the acuminate tip: corolla violet-blue (or sometimes purplish?), tubular, but slightly dilated upward, $\mathrm{I} 2-\mathrm{I} 5^{\mathrm{mm}}$ long. only 
moderately bilabiate ; the lobes entire, rounded, sparsely bearded on the lower lip: sterile filament but slightly enlarged upward, rather stiffly bearded at tip; anthers dehiscent through the junction of the cells, but not explanate.

That the large number of forms that have figured as $P$. confertus Dougl. and varieties of it have given rise to no little trouble is admitted by all. An aggregate is always confusing. As tending toward a simplification, it seemed to every one proper to restore to specific rank $P$. procerus Bougl., published by Graham in Edinb. Phil. Journ., I829. This, so long known as P. confertus caeruleo-purpureus, is so evidently distinct that no one ever thinks of mistaking it for the species to which it has been appended.

The species now proposed, while a member of this same group, is as distinct from $P$. procerus as the latter is from $P$. confertus. The habitat of the two is characteristic. $P$. procerus is found at middle elevations and up to the limit of trees, occurring on moist slopes and in the valleys. P. Owenii is strictly alpine and occurs in clumps among the rocks of the "slides." The former is glabrous, the latter puberulent on the stems and glandular-pubescent on the inflorescence. The inflorescence of the former is nominally verticillastriform, of two to five rather remote verticils; the latter is spicate-capitellate with at most one proximate verticil, and the corollas of the latter are much larger than in the normal form of the other, less strongly bilabiate, and relatively longer when compared with the calyx.

This species is dedicated to that intrepid mountaineer, Hon. W. O. Owen, who in September I 898 , with a small party, successfully scaled the Grand Teton and left upon its summit permanent record of the achievement. Mr. Owen brought back from this memorable trip several specimens of alpine plants, among which was a specimen of this species. It has been collected again in 1899 , August 16 , by the writer, this time also on the Tetons at an alpine station, no. 6515 being the type. More recently collected by Messrs. Merrill and Wilcox, I gor, and again on the Tetons.

Synthyris flavescens, n. sp.-Nearly glabrous throughout from the first, green even to the floral bracts: rhizome thick, short, horrizontal, with numerous thick, fibrous roots: stems few to several, strict, leafy-bracteate, $3-5^{\mathrm{dm}}$ high: leaves few, radical, ovate-lanceolate, sub-acute, finely serrate-crenate, 6-10 $\mathrm{cm}^{\mathrm{m}} \mathrm{long}$, mostly exceeding the comparatively slender petioles; the foliar bracts of the stem broadly ovate, acute, serrations similar to those of the leaves, I-2 $2^{\mathrm{cm}}$ long; floral bracts ovate-rhomboid to lanceolate, acute, entire or very unequally two-lobed, sessile 
by a narrowed base, sparingly ciliate-margined as are also the sepals: spike dense, $5-10^{\mathrm{cm}}$ long; the flowers short-pediceled: calyx unequally 4-cleft, the lobes elliptic, toothed at apex: corolla yellow or greenish-yellow, cleft at either side nearly to the base ; the upper lip broadly obovate, with cuneate base and entire or toothed summit, exceeding the calyx and the $2-3$-cleft lower lip by about half: stamens exserted, with purplish filaments and yellow anthers: mature fruits not at hand.

This species was collected and distributed by Professor C. S. Crandall as $S$. plantaginea Benth. To this it is allied, but more closely to $S$. Ritteriana Eastwood, though even from this it differs in many essential respects. Collected at Cimarron, Montrose co., Colo., May i8, i 898.

Synthyris Ritteriana obtusa, n. var.-Leaves very obtuse, exceeding the scarcely margined petiole; foliar bracts suborbicular, usually cuspidate; floral bracts merely acute, distinctly purple-veined on the inside, with a narrowed base but not petioled : calyx parted to the base at the sides, the two lobes similar, orbicular or reniform, sometimes one or both from slightly to deeply cleft near one side, thus giving a 3 or 4 -cleft calyx of unequal lobes: corollas yellowish-white, slightly exceeding the calyx, the two lips parted to the base; the upper lip rounded or truncate; the lower nearly similar or laciniately toothed or lobed.

If the above characters, which are mainly points of distinction between this plant and $S$. Ritteriana, are not specific, they at least call attention to a good variety. The specimens are those distributed by Messrs. Baker, Earle, and Tracy, no. 225, as S. Ritteriana, and bearing the note "this but a short distance from the type locality where it was also observed." In spite of the locality, the plant fails to measure up to the characters, and must be at least varietally distinct. In case the now proposed variety must later be included into the species, the description of the latter will have to be materially modified; but in the absence of the type specimen I leave it as a variety.

Gaertneria tomentosa (Nutt.), n. comb.-Ambrosia tomentosa Nutt. Gen. 2: 186. I8 18; Franseria discolor Nutt., Trans. Am. Phil. Soc. n. ser. 7:345. I84I; Xanthidium discolor Delpino, Studi sopra Artemis 62. I871.- That Nuttall's Franseria discolor is simply his Ambrosia tomentosa seems more than probable. As 
Dr. Gray states in the Syn. Fl., "station and characters" indicate this. In the Kew Index this synonomy is accepted without question. Then, too, Nuttall's characterization, "leaves tomentose on the lower surface," would imply that the upper surface was not tomentose. It is true also that while Dr. Gray in $\mathrm{Pl}$. Fendl. thought his Franseria tomentosa was Nuttall's Ambrosia tomentosa, he changed his mind about the matter in a later publication (Syn. Fl. 25 I).

Gaertneria Grayi, n. nom.-Franseria tomentosa Gray, Pl. Fendl. 80.- Since the preceding change necessitates another, this species may appropriately be dedicated to the original describer.

UNIVERSITY OF WYOMING, Laramie, Wyoming. 


\section{$2 \mathrm{BHL}$ Biodiversity Heritage Library}

Nelson, Aven. 1902. "Contributions from the Rocky Mountain Herbarium. III." Botanical gazette 34(1), 21-35. https://doi.org/10.1086/328257.

View This Item Online: $\underline{\text { https://www.biodiversitylibrary.org/item/91645 }}$

DOI: https://doi.org/10.1086/328257

Permalink: https://www.biodiversitylibrary.org/partpdf/223118

\section{Holding Institution}

Missouri Botanical Garden, Peter H. Raven Library

\section{Sponsored by}

Missouri Botanical Garden

\section{Copyright \& Reuse}

Copyright Status: Public domain. The BHL considers that this work is no longer under copyright protection.

This document was created from content at the Biodiversity Heritage Library, the world's largest open access digital library for biodiversity literature and archives. Visit BHL at https://www.biodiversitylibrary.org. 